\title{
Effect of Irrigation Intervals and Potassium Application Methods on Yield and Yield Components of Wheat Crop Irrigated with Surge Flow
}

\author{
Hussiun M.A. Ragheb, Saleh M. Ismail, Hala H. Gomah, and Ahmed M. Abd El kawy* \\ ${ }^{1}$ Professors of Soil and Water Department, Faculty of Agriculture, "Ph.D. Student at Soil and Water \\ Department, Faculty of Agriculture, Assiut University, Assiut, Egypt
}

\begin{abstract}
Field experiments were carried out for two consecutive seasons at the Experimental Station of Soil and Water Department, Faculty of Agricultural, Assiut University, to study the effect of both irrigation intervals and methods of potassium application on yield and yield components of wheat (Triticum aestivum L.) beside potassium content in plant and soil. The experimental design was a split plot design with four replications. The main plots were three irrigation intervals (15, 21 and 28 days), while the sub- plots contained two methods of potassium application (side dressing and fertigation). Results indicated that, shorter irrigation intervals improved yield and yield components of wheat crop. The best yield was obtained from 15 days irrigation interval followed by 21 days. Longer irrigation interval ( 28 days) produced the least yield and yield components due to water stress conditions. Applying potassium with irrigation water improved yield of wheat crop and potassium contents in grain and straw yields compared to side dressing application. Also it increased the available potassium in soils.
\end{abstract}

Keywords: Surge flow; irrigation interval; wheat; fertigation; potassium; furrow irrigation.

\section{Introduction}

Egypt is a country with tremendous land resources but limited water resources. All cultivated areas in Egypt are 100\% irrigated. About $85 \%$ of irrigated areas are subjected to surface (gravity) irrigation which characterized by low water use efficiency. In such condition using applied techniques like surge flow with different irrigation intervals may improve water use efficiency.

Reducing the time interval between successive irrigations in order to maintain constant, optimal water content in the root zone may reduce the variations in nutrient concentration, thereby increasing their availability to plants. The higher number of pulses per each irrigation had significant effect on yield and nutrients concentration. Thus, it is recommended to apply irrigation water at three or four times per each irrigation (El Hawary, et al., 2011).

Plant height increased with more frequent irrigation and decreased with less frequent irrigation (El Monyeri, et al., 1982). In a study carried out by El Hawary, et al. (2011) short irrigation intervals (7, 10 and 14 days) increased plant height compared to the long

irrigation intervals (21 and 28 days). Shorter irrigation intervals resulted in higher biomass and straw yield of wheat crop (Hamissa and Moustafa, 1998; El Hawary et al., 2011). 
Deficit irrigation is an optimization strategy that is used to reduce water use and to increase water use efficiency. Increasing irrigation interval at different growth stages is considered a kind of deficit irrigation. Applying that technique on maize crop showed a yield reduction which was mainly due to the lower number of grains per square meter. Higher interval between irrigations during the grain filling phase did not significantly affect crop growth and yield. The obtained results revealed that, it was possible to maintain relatively high yields in maize if small water deficits caused by the increase in irrigation intervals in all growth stages except for the flowering stage, (Zwart and Bastiaanssen, 2004). Increasing soil moisture depletion by decreasing the amount of irrigation progressively from ear-emergence to harvest, reduced straw and grain yields of wheat, (El Hawary, et al., 2011).

Another mechanism to improve plant tolerance to drought stress is applying potassium (K). It seems that, it has a beneficial effect on overcoming soil moisture stress (Reddya et al., 2004). Increased application of $\mathrm{K}$ has been shown to enhance photosynthetic rate, plant growth and yield in different crops under water stress conditions (Tiwari et al., 1998; Egilla et al., 2001). Spraying wheat plants with $\mathrm{K}$ before subjecting the plants to drought treatment diminished the negative effects of drought on growth and in turn increases yield per plant (El-Ashry and ElKholy, 2005). Under water-deficit conditions, $\mathrm{K}$ nutrition increases crop tolerance to water stress by utilizing the soil moisture more efficiently than in K-deficient plants. The positive effects of $\mathrm{K}$ on water stress tolerance may be through promotion of root growth accompanied by a greater uptake of nutrients and water by plants (Rama Rao, 1986). K also help to maintains the osmotic potential, turgor of the cells and regulates the stomatal functioning which resulted enhancement in photosynthetic rate, growth characteristics and finely improved crop yield under water stress conditions (Umar, 2006; Kant and Kafkafi, 2002; Umar and Moinuddin, 2002). The protective role of $\mathrm{K}$ in plants suffering from drought stress could also be attributed to the maintenance of a high $\mathrm{pH}$ in stroma and against the photo-oxidative damage to chloroplasts (Cakmak, 1997).

The main goal of the current study was to achieve the greatest yield per unit of water applied. Beside the main goal of this research, the effect of irrigation interval and potassium application method on yield and yield components of wheat and potassium content in straw and grain yield beside the available potassium in soil were investigated.

\section{Materials and Methods}

\section{Experimental location, design and treatments}

The experiment was carried out at the Experimental Station of Soil and Water Department, Faculty of Agricultural, Assiut University, located at 27011 'N latitude, 310 $10^{\prime} \mathrm{E}$ longitude, Assiut, Egypt for two consecutive winter seasons of 2007/08 and $2008 / 09$. The soil is classified as clay soil. Detailed description of the soil physical and chemical characteristics is presented in Table 1. The design of the experiment was a split plot design with four replications. The main plots contained three irrigation interval treatments including irrigation every 15 days (W1), Irrigation every 21 days (W2) and irrigation every 28 days (W3). The sub- plots included two method of application for potassium namely: Fertigation With Irrigation Water (FWIW) and Soil Application Side Dressing (SASD). Potassium was applied at a level of $48 \mathrm{~K}_{2} \mathrm{O} \mathrm{kg} / \mathrm{fed}\left(\right.$ Feddan $\left.=4200 \mathrm{~m}^{2}\right)$ in the form of potassium sulfate $\left(48 \% \mathrm{~K}_{2} \mathrm{O}\right)$. The amounts of potassium fertilizer were added as FWIW and SASD in both seasons. Nitrogen 
was applied at a level of $100 \mathrm{~kg} \mathrm{~N} /$ fad in the form of urea $(46.5 \% \mathrm{~N})$. Both nitrogen and potassium fertilizers were divided into two equal doses and were added after 21 days from cultivation and during heading. Phosphorus was broadcasted at a level of $100 \mathrm{~kg} / \mathrm{fed}$. in the form Super phosphate $\left(15.5 \% \mathrm{P}_{2} \mathrm{O}_{5}\right)$ before sowing.

\section{Cultural practices}

At the beginning of November land was disc-plough and harrowing then, leveling. The soil was ridged at a spacing of $70 \mathrm{~cm}$. Wheat grains (Triticum aestivum vulgar), cultivar name (c.v Giza 168), were manually sown at furrow ridged in lines with a distance of $20 \mathrm{~cm}$ between lines and $5 \mathrm{~cm}$ between plants at $3 \mathrm{~cm}$ depth on $4^{\text {th }}$ of December, 2007 and $7^{\text {th }}$ of December 2008 for the two growing seasons with a rate of $60 \mathrm{~kg} / \mathrm{fed}$. Wheat plants were harvested at the end of April in both seasons. All agricultural practices for wheat crop were applied as recommended by the Ministry of Agriculture, Egypt.

Table 1. The main physical and chemical properties of the experimental soil.

\begin{tabular}{|c|c|}
\hline Parameters & Value \\
\hline $\begin{array}{c}\text { Particle size distribution } \\
\text { Sand \% } \\
\text { Clay } \% \\
\text { Silt } \% \\
\text { Grade }\end{array}$ & $\begin{array}{l}21.7 \\
51.6 \\
26.7 \\
\text { Clay }\end{array}$ \\
\hline Wilting point $\%$ & 27.5 \\
\hline Field capacity \% & 47 \\
\hline Saturation $\%$ & 61.7 \\
\hline Bulk density $\mathrm{kg} / \mathrm{m}^{3}$ & 1.20 \\
\hline \multicolumn{2}{|l|}{ Chemical analysis } \\
\hline Organic matter $\%$ & 1.4 \\
\hline $\mathrm{pH}_{(\text {Susp, 1:1) }}$ & 7.74 \\
\hline $\mathrm{EC}_{(\mathrm{Extr}, 1: 1),}\left(\mathrm{dS} \mathrm{m}^{-1}\right)$ & 2.00 \\
\hline Total nitrogen $\%$ & 0.1 \\
\hline Available $\mathrm{P}\left(\mathrm{NaHCO}_{3}-\mathrm{P}\right) \mathrm{ppm}$ & 10 \\
\hline Available $\mathrm{K}\left(\mathrm{NH}_{4} \mathrm{OAC}-\mathrm{K}\right)$ & 0.69 \\
\hline
\end{tabular}

\begin{tabular}{|c|c|}
\hline Soluble Cations, meq /100 gm soil & \\
$\mathrm{Ca}^{2+}$ & 0.95 \\
$\mathrm{Mg}^{2+}$ & 0.30 \\
$\mathrm{Na}^{+}$ & 0.50 \\
$\mathrm{~K}^{+}$ & 0.23 \\
\hline Soluble Anions, meq /100 gm soil & \\
$\mathrm{Cl}^{-}$ & 0.40 \\
$\mathrm{HCO}_{3}-\mathrm{CO}_{3}^{2-}$ & 0.75 \\
$\mathrm{SO}_{4}{ }^{2-}$ & 1.31 \\
\hline
\end{tabular}

\section{Measuring yield and yield components}

The studied yield components including plant height $(\mathrm{cm})$, spike length $(\mathrm{cm})$ and number of spikes $/ \mathrm{m}^{2}$, were measured during harvesting in 10 guarded plants randomly selected in each plot for each treatment. Grain and straw yield in one square meter in the middle of each plot were measured and then calculated for feddan.

\section{Plant analysis}

Plant samples of wheat were taken for analysis after 75 days of planting and after harvesting. The samples were freshly weight, and then washed with tap water, followed with distilled water, air dried, oven dried, then grinded and stored for chemical analysis. Samples $(0.5 \mathrm{~g})$ of grinded shoots and grains were prepared for the wet digestion using a mixture of sulfuric acid and hydrogen peroxide (Parkinson and Allen, 1975). Total potassium in the plant digest was determined by the flam photometer (Jackson, 1973)

\section{Soil analysis}

Representative soil samples $(0-30 \mathrm{~cm})$ from different experimental sites were air dried and pulverized to pass a $2 \mathrm{~mm}$ sieve and prepared for analysis. Soil texture was carried out using the pipette method (Piper, 1950); electrical conductivity $\left(\mathrm{EC}_{1: 1}\right)$ was determined using an EC meter; soil $\mathrm{pH}_{(1: 1)}$ was measured using a glass electrode; organic matter content was measured by the modified Walkely-Black method; calcium and magnesium were titrated 
by versenate method while sodium and potassium were measured by flame photometer. Available phosphorus was extracted according to Olsen method. Available potassium was extracted by ammonium acetate method at $\mathrm{pH} 7.00$ and measured by flame photometry (Jackson, 1973). Total nitrogen was determined using the micro-kjeldahl method (Page et al, 1982).

\section{Statistical Analysis}

The collected data were statistically analyzed using the analysis of variance procedures (SAS, 2006) and mean separation using the least significant differences (LSD) test based on the experimental design.

\section{Results}

Effect of irrigation intervals and potassium application method on plant height, spike length and number of spike/m ${ }^{2}$

Results presented in Table 2 indicated that, irrigation at 15 days and 21 days interval significantly increased plant height by $3.55 \%$ and $2.77 \%$ in the first season and by $2.75 \%$ and $2.54 \%$ in the second season respectively, compared with plant height of 28 days interval. Results presented in Table 2 also revealed that, irrigation at 15 days intervals significantly increased spikes length $(13.5 \mathrm{~cm}$ and $13.6 \mathrm{~cm}$, first and second seasons, respectively) followed by irrigation at 21 days interval (of $12.9 \mathrm{~cm}$ and $13.3 \mathrm{~cm}$, first and second seasons, respectively) compared to 28 days interval $(11.3 \mathrm{~cm}$ and $11.1 \mathrm{~cm}$ ) for first and second seasons, respectively).

Results of the number of spikes $/ \mathrm{m}^{2}$ presented in Table 2 indicated that, 15 and 21 days irrigation intervals significantly increased number of spikes $/ \mathrm{m}^{2}$ by $21.4 \%$ and $15.6 \%$ in the first season, and by $25.6 \%$ and $17.4 \%$ in the second season compared to those of 28 days irrigations intervals. Concerning the effect of potassium application method on number of spike the results revealed that FWIW resulted in non-significant increase in number of spike $/ \mathrm{m}^{2}$ compared with SASD application method. Results of the interaction between irrigation intervals and $\mathrm{K}$ application methods insignificantly affected the plant height, spike length and number of spike $/ \mathrm{m}^{2}$.

\section{Effect of irrigation intervals and potassium application methods on dry matter and grain and straw yields}

Results of plant dry matter weight and grain and straw yields of wheat under the studied treatments are presented in Table 3. The results revealed that, irrigation intervals of 15 and 21 days significantly increased dry matter weight by about $27.0 \% \%$ and $8.70 \%$ in the first season, and by $15 \%$ and $8.76 \%$ in the second season compared to 28 days irrigation intervals, respectively. The highest dry matter was obtained from W1 followed by W2 and W3, respectively. Regarding the effect of potassium application methods, results showed that, FWIW insignificantly increased dry matter weight compared with SASD in both seasons, respectively.

Results of wheat grain yield/fed presented in Table 3 clearly showed significant differences among investigated irrigation intervals. The highest grain yields $(2.47$ and 2.76 ton/fed) were obtained from W1 followed by W2 (2.37 and 2.54 ton/fed) in both 2007 and 2008 growing seasons, respectively. The least grain yields (1.81 ton/fed in the first season and 2.35 ton/fed. in the second season) were recorded in W3. FWIW potassium application method increased grain yield compared to SASD, however, the differences in grain yield was not significant. Result of straw yield show similar behaviors as indicated in grain yield. Also, the results revealed that dry matter yield, grain and straw yield were higher in the second growing season compared with those of first growing 
season. The dray matter and grain and straw yields in both growing seasons were not significantly affected by the interaction between irrigation interval and potassium application method.

Table 2. Effect of irrigation intervals and potassium application method on plant height, spike length and number of spikes/ $\mathbf{m}^{2}$ of wheat during $2007 / 08$ and $2008 / 09$ seasons.

\begin{tabular}{|c|c|c|c|c|c|c|c|}
\hline $\begin{array}{l}\text { Irrigation } \\
\text { interval }\end{array}$ & K applc. method & \multicolumn{2}{|c|}{$\begin{array}{c}\text { Plant height } \\
(\mathrm{cm})\end{array}$} & \multicolumn{2}{c|}{$\begin{array}{c}\text { Spikes length } \\
(\mathrm{cm})\end{array}$} & \multicolumn{2}{c|}{$\begin{array}{c}\text { Number of } \\
\text { spikes } / \mathrm{m}^{2}\end{array}$} \\
\hline \multirow{3}{*}{$\begin{array}{c}\text { W1 } \\
(15 \text { days })\end{array}$} & SASD & $2007 / 08$ & $2008 / 09$ & $2007 / 08$ & $2008 / 09$ & $2007 / 08$ & $2008 / 09$ \\
\cline { 2 - 8 } & FWIW & 126.8 & 126.5 & 13.5 & 13.5 & 434.0 & 450.3 \\
\cline { 2 - 8 } & Mean & 126.9 & 126.3 & 13.5 & 13.8 & 438.0 & 470.8 \\
\hline \multirow{3}{*}{$\begin{array}{c}\text { W2 } \\
(21 \text { days })\end{array}$} & SASD & 126.3 & 126.5 & 13.5 & 13.6 & 436.0 & 460.5 \\
\cline { 2 - 8 } & FWIW & 126.5 & 126.8 & 13.0 & 13.3 & 405.0 & 422.5 \\
\cline { 2 - 8 } & Mean & 126.4 & 126.6 & 12.9 & 13.3 & 406.0 & 406.3 \\
\hline \multirow{3}{*}{\begin{tabular}{c} 
W3 days \\
\cline { 2 - 8 }
\end{tabular}} & SASD & 122.8 & 122.5 & 11.3 & 11.0 & 333.0 & 414.4 \\
\cline { 2 - 8 } & FWIW & 123.0 & 123.5 & 11.3 & 11.3 & 351.0 & 351.3 \\
\hline \multirow{3}{*}{ LSD $_{0.05}$} & Mean & 122.9 & 123.0 & 11.3 & 11.1 & 342.0 & 342.5 \\
\cline { 2 - 8 } & Irrigation interval & 0.82 & 1.39 & 0.66 & 0.48 & 5.06 & 17.21 \\
\cline { 2 - 8 } & K appl. method & N.S. & N.S. & N.S. & N.S. & N.S. & N.S. \\
\cline { 2 - 8 } & interaction & N.S. & N.S. & N.S. & N.S. & N.S. & N.S. \\
\hline
\end{tabular}

N.S.: not significant at $\mathrm{p} \leq 0.05$.

Table 3. Effect of irrigation intervals and potassium application method on dry matter, grain and straw yields of wheat during 2007/08 and 2008/09 seasons.

\begin{tabular}{|c|c|c|c|c|c|c|c|}
\hline \multirow[t]{2}{*}{$\begin{array}{l}\text { Irrigation } \\
\text { interval }\end{array}$} & \multirow[t]{2}{*}{$\begin{array}{l}\text { K appl. } \\
\text { method }\end{array}$} & \multicolumn{2}{|c|}{$\begin{array}{l}\text { Plant dry matter } \\
\text { weight }(\mathrm{g})\end{array}$} & \multicolumn{2}{|c|}{$\begin{array}{c}\text { Grain yield } \\
\text { ton/fed }\end{array}$} & \multicolumn{2}{|c|}{$\begin{array}{c}\text { Straw yield } \\
\text { ton/fed }\end{array}$} \\
\hline & & $2007 / 08$ & $2008 / 09$ & $2007 / 08$ & $2008 / 09$ & $2007 / 08$ & $2008 / 09$ \\
\hline \multirow{3}{*}{$\begin{array}{c}\text { W1 } \\
\text { (15 days) }\end{array}$} & SASD & 75.3 & 70.7 & 2.47 & 2.75 & 5.78 & 6.47 \\
\hline & FWIW & 76.1 & 71.3 & 2.49 & 2.77 & 5.84 & 6.51 \\
\hline & Mean & 75.7 & 71.0 & 2.48 & 2.76 & 5.81 & 6.49 \\
\hline \multirow{3}{*}{$\begin{array}{c}\text { W2 } \\
\text { (21days) }\end{array}$} & SASD & 59.9 & 64.3 & 2.37 & 2.53 & 5.55 & 5.95 \\
\hline & FWIW & 61.2 & 67.7 & 2.37 & 2.54 & 5.56 & 5.96 \\
\hline & Mean & 60.5 & 66.0 & 2.37 & 2.54 & 5.56 & 5.96 \\
\hline \multirow{3}{*}{$\begin{array}{c}\text { W3 } \\
\text { (28 days) }\end{array}$} & SASD & 51.7 & 60.8 & 1.79 & 2.34 & 4.19 & 5.49 \\
\hline & FWIW & 58.9 & 59.6 & 1.81 & 2.35 & 4.24 & 5.51 \\
\hline & Mean & 55.3 & 60.2 & 1.80 & 2.35 & 4.22 & 5.50 \\
\hline \multirow{3}{*}{$\operatorname{LSD}_{0.05}$} & $\begin{array}{l}\text { Irrigation } \\
\text { interval }\end{array}$ & 7.73 & 4.47 & 0.02 & 0.02 & 0.05 & 0.05 \\
\hline & $\begin{array}{l}\mathrm{K} \text { appl. } \\
\text { method }\end{array}$ & N.S & N.S & N.S & N.S & N.S & N.S \\
\hline & interaction & N.S & N.S & N.S & N.S & N.S & N.S \\
\hline
\end{tabular}

N.S. : not significant at $\mathrm{p} \leq 0.05$. 
Effect of irrigation intervals and potassium application method on potassium content in wheat grains and straw

Results of potassium content in grain and straw yield presented in Table 4 revealed that, short irrigation interval significantly increased potassium uptake in both grain and straw yields compared to long irrigation intervals. The highest significant potassium content (\%) in gain and straw yields obtained from W1 followed by W2 and W3 in both growing seasons, respectively. The potassium content was higher in the second season compared with that of the first growing season, respectively. Results concerning the effect of the potassium application method presented also in Table 4 clearly showed significant increase in potassium content in grain and straw yields for FWIW compared

Table 4. Effect of irrigation intervals and potassium application method on potassium content (\%) in wheat straw and grain during 2007/08 and 2008/09 seasons.

\begin{tabular}{|c|c|c|c|c|c|}
\hline \multirow{2}{*}{$\begin{array}{c}\text { Irrigation } \\
\text { interval }\end{array}$} & \multirow{2}{*}{ K appl. method } & \multicolumn{2}{|c|}{ Wheat Straw } & \multicolumn{2}{|c|}{ Wheat Grain } \\
\hline & & $2007 / 08$ & $2008 / 09$ & $2007 / 08$ & $2008 / 09$ \\
\hline \multirow{3}{*}{$\begin{array}{c}\text { W1 } \\
\text { (15 days) }\end{array}$} & SASD & 1.150 & 1.365 & 0.460 & 0.468 \\
\hline & FWIW & 1.215 & 1.382 & 0.483 & 0.472 \\
\hline & Mean & 1.183 & 1.374 & 0.472 & 0.470 \\
\hline \multirow{3}{*}{$\begin{array}{c}\text { W2 } \\
\text { (21days) }\end{array}$} & SASD & 1.127 & 1.305 & 0.443 & 0.458 \\
\hline & FWIW & 1.188 & 1.307 & 0.478 & 0.465 \\
\hline & Mean & 1.158 & 1.306 & 0.461 & 0.462 \\
\hline \multirow{3}{*}{$\begin{array}{c}\text { W3 } \\
\text { (28 days) }\end{array}$} & SASD & 1.083 & 1.120 & 0.430 & 0.422 \\
\hline & FWIW & 1.085 & 1.180 & 0.458 & 0.453 \\
\hline & Mean & 1.084 & 1.150 & 0.444 & 0.438 \\
\hline \multirow{3}{*}{$\mathrm{LSD}_{0.05}$} & Irrigation interval & 0.053 & 0.063 & 0.020 & 0.010 \\
\hline & Irrigation interval & 0.017 & 0.026 & 0.010 & 0.012 \\
\hline & K appl. method & 0.030 & N.S & N.S & N.S \\
\hline
\end{tabular}

N.S.: not significant at $\mathrm{p} \leq 0.05$.

with SASD in both growing seasons, respectively. Results of the interaction between irrigation interval an potassium application method were only significant on potassium content in straw yield during the growing seasons of 2007/2008.

\section{Effect of irrigation intervals and potassium application method on potassium content in soil}

Soluble potassium significantly increased with decreasing irrigation intervals in both seasons due to the increasing amounts of soil water (Table 5). The 15 and 21 days irrigation intervals significantly increased soluble potassium by $10 \%$ and $5.26 \%$ in the first season, and by $7.32 \%$ and $2.56 \%$ in the second season, respectively compared to 28 days irrigation intervals. Exchangeable K was gradually and significantly increased by increasing irrigation intervals in both seasons and soil sampling periods (after 75 days and after harvesting). Results of exchangeable potassium obtained from the analysis of soil sampled after 75 dyes, revealed that, irrigation intervals of 28 days significantly increase exchangeable potassium by $4.3 \%$ and $2.4 \%$ in the first season, and by $4.3 \%$ and $3.8 \%$ in the second season compared with 15 and 21 days, respectively.

Exchangeable potassium after wheat harvest was significantly increased by $2.6 \%$ and $1.7 \%$ in the first season, and by $8.8 \%$ and $7.4 \%$ in the second season compared with 15 and 21 days, respectively. Potassium application method show almost similar 
effects on either soluble or exchangeable soil potassium in both investigated seasons and time periods. In both seasons, the soluble and exchangeable potassium were not significantly affected by the interaction between irrigation interval and potassium application method (Table 5).

Table 5. Effect of irrigation intervals and potassium application method on soluble and exchangeable potassium in soil (meg/100 g soil) during 2007/08 and 2008/09 seasons.

\begin{tabular}{|c|c|c|c|c|c|c|c|}
\hline \multirow{2}{*}{$\begin{array}{c}\text { Irrigation } \\
\text { interval }\end{array}$} & \multirow{2}{*}{ K appl. method } & \multicolumn{4}{|c|}{ Age 75 day } & \multicolumn{2}{c|}{ After harvesting } \\
\cline { 3 - 8 } & & \multicolumn{2}{|c|}{ soluble K } & \multicolumn{2}{c|}{ Exchangeable K } & \multicolumn{2}{c|}{ Exchangeable K } \\
\hline \multirow{3}{*}{$\begin{array}{c}\text { W1 } \\
\text { (15 days })\end{array}$} & SASD & $2007 / 08$ & $2008 / 09$ & $2007 / 08$ & $2008 / 09$ & $2007 / 08$ & $2008 / 09$ \\
\cline { 2 - 8 } & FWIW & 0.040 & 0.042 & 0.691 & 0.686 & 0.572 & 0.590 \\
\hline \multirow{3}{*}{$\begin{array}{c}\text { W2 } \\
(21 \text { days })\end{array}$} & Mean & 0.040 & 0.040 & 0.690 & 0.683 & 0.571 & 0.587 \\
\cline { 2 - 8 } & SASD & 0.038 & 0.039 & 0.691 & 0.685 & 0.572 & 0.589 \\
\hline \multirow{3}{*}{$\begin{array}{c}\text { W3 } \\
(28 \text { days })\end{array}$} & FWIW & 0.037 & 0.038 & 0.703 & 0.690 & 0.578 & 0.598 \\
\cline { 2 - 8 } & Mean & 0.038 & 0.039 & 0.704 & 0.689 & 0.577 & 0.596 \\
\hline \multirow{3}{*}{ LSD $_{0.05}$} & SASD & 0.037 & 0.038 & 0.722 & 0.718 & 0.590 & 0.597 \\
\cline { 2 - 8 } & FWIW & 0.036 & 0.037 & 0.720 & 0.714 & 0.584 & 0.643 \\
\cline { 2 - 8 } & K appl. method & 0.037 & 0.038 & 0.721 & 0.716 & 0.587 & 0.646 \\
\cline { 2 - 8 } & Interaction & 0.001 & 0.001 & 0.008 & 0.009 & 0.006 & 0.012 \\
\hline
\end{tabular}

N.S. : not significant at $\mathrm{p} \leq 0.05$.

\section{Discussion}

Results clearly revealed that short irrigation interval increased plant height, spike length and number of spikes $/ \mathrm{m}^{2}$ compared to long irrigation interval. The results may be attributed to positive effect of more available moisture through shorter irrigation intervals on number of cells through cell division or cell size through cell enlargement and turgidity consequently, increased meristemic growth (Haikl and Melegy, 2005). Shorter irrigation intervals (7, 10 and 14 days) resulted in taller plants and greater number of spikes $/ \mathrm{m}^{2}$ compared to the longer irrigation intervals (El Hawary, et al., 2011). Longer irrigation interval may result in water deficit in plant. Water deficit affects number of spikes $/ \mathrm{m}^{2}$. Practicing full irrigation with no irrigation before stem elongation produced the highest spikes $/ \mathrm{m}^{2}$ while stop irrigation or practicing water deficit before grain filling produced the least spikes $/ \mathrm{m}^{2}$ ( Akbari et al., 2011)
The reduction in dry matter accumulation, grain yield and straw yield was increased by increasing irrigation interval and may be attributed to unbalanced soil water-air relations which reduce photosynthetic activity and unbalanced relations between plant hormones and biological processes in the whole plant organs (Schneider and Howell, 1997). Grain yield was significantly reduced under longer irrigation intervals due to lower number of tillers/plant, number of spikes $/ \mathrm{m}^{2}$, number of spikelet's/spike, number of grains/spike and 1000-grains weight (Sarwar, et al., 2010; Zareian, et al., 2014). Potassium fertilizer application in deficit irrigation treatments increased grain yield more than full irrigation treatment. Biologic yield and harvest index were increased with consumption of 300 $\mathrm{kg} \mathrm{K} \mathrm{ha}{ }^{-1}$ relative to control by about $24 \%$ (Bahrani, et al., 2012). Increasing soil moisture depletion by decreasing the amount of irrigation progressively from ear-emergence 
to harvest, reduced straw and grain yields (Zhang, et al., 2004).

Applying $\mathrm{K}$ with irrigation water slightly increased straw yield compared with side dressing application. Increasing potassium uptake by plant improves plant growth and performance. One of the mechanisms for improving plant tolerance to drought is to apply $\mathrm{K}$ which seems to have a beneficial effect in overcoming soil moisture stress (Marchner, 1995; Reddya, et al., 2004).

In plants growing under drought stress, the accumulation of $\mathrm{K}^{+}$may be more important than the production of organic solutes during the initial adjustment phase, because osmotic adjustment through ion uptake like $\mathrm{K}^{+}$is more energy efficient (Hsiao, 1973). Lower water loss of plants well supplied with $\mathrm{K}^{+}$is due to a reduction in transpiration which not only depends on the osmotic potential of mesophyll cells but also is controlled to a large extent by opening and closing of stomata (Fusheing, 2006).

In all treatments, exchangeable $\mathrm{K}$ was always decreased with time (after 75 days and after wheat harvest). The results are logic and expected due to the continual absorption by plant. Similar results were reported by Hamissa and Moustafa (1998).

\section{Conclusion}

The obtained results clarified that, shorter irrigation intervals improved yield and yield components of wheat. The best yield was obtained from 15 days irrigation interval followed by 21 days. The 28 irrigation intervals produced the least yield and yield components due to depletion of growth under water stress. Applying potassium with irrigation water improved potassium contents in grain and straw compared to side dressing application. Also it increased the available potassium in soils. In conclusion, applying $\mathrm{K}$ with irrigation water using 15 days irrigation intervals is recommended for higher wheat yield and better soil fertility under the conditions of this experiment.

\section{References}

Akbari, M. H, Galavi M., Fanaei H.R., Koohkan S.H., Poodineh O. (2011) Effects of deficit irrigation on grain yield and some morphological traits of wheat cultivars in drought - prone conditions, International Journal of Agri Science, 1 (4): 249-257.

Bahrani, A., Pourreza, J., Madani, A. and Amiri, F. (2012) Effect of PRD irrigation method and potassium fertilizer application on corn yield and water use efficiency, Bulgarian Journal of Agricultural Science, 18 (4): 616625.

Cakmak, I. (1997) Role of potassium in protecting higher plants against photo-oxidative damage. In: Johnston, A.E. (Ed.), Food Security in the WANA Region, the Essential Need for Balanced Fertilization, International Potash Institute, Basel, Switzerland, pp: 345-352.

Egilla, J.N., Davies, J. F.T. and Drew, M.C. (2001) Effect of potassium on drought resistance of Hibiscus rosa-sinensis cv. Leprechaun: plant growth, leaf macro and micronutrient content and root longevity, Plant Soil, 229: 213-224.

El Hawary, A., El Tahir, B. and Yagoub, S. O. (2011) Effect of Different Irrigation Intervals on Wheat (Triticum aestivum L) in Semiarid Regions of Sudan, Journal of Science and Technology, 12 (03). ISSN 1605 - 427X.

El Monyeri, M.O., Hegazi, M. N., Ezzat, N.H., Salem, H. M. and Tahoun, S. M. (1982) Growth and yield of some wheat and barley varieties grown under different moisture stress levels, Field crop abstracts, 36, Abstract No.9.

El-Ashry, M.S. and El-Kholy, M.A. (2005) Response of wheat cultivars to chemical desiccants under water stress conditions, Journal of Applied Sciences Research, 1 (2): 253-262.

Fusheing, L. (2006) Potassium and water interaction. International workshop on soil potassium and $\mathrm{K}$ fertilizer management, Agricultural College Guangxi University, 132 .

Haikle, M. A. and El Melegy, A. M. (2005) Effect of irrigation requirements, seeding rates and bio-mineral fertilizer on wheat prod-uctivity in newly reclaimed soil under sprinkler irrigation system, J. Productivity and Development, 10 :113-134.

Hamissa, M. R. and Moustafa, A. T. (1998) Fertilizer management practices for wheat using tracer technique for nitrogen and phosphorous. Advances in Agricultural Research in Egypt, special issue, 1 (1). 
Hsiao, T.C. (1973) Plant responses to water stress. Ann. Rev. Plant Physiol, 24: 519-570.

Jackson, M. L. (1973) Soil Chemical Analysis, Prentice-Hall of India Private Limited, New Delhi, India

Kant, S. and Kafkafi, U. (2002) Potassium and Abiotic Stresses in Plants. In: Pasricha, N. S., Bansal, S. K. (Eds.), Potassium for Sustainable Crop Production, Potash Institute of India, Gurgaon, India, pp: 233-251.

Marschner, H. (1995) Mineral nutrition of higher plants. Ed Academic Press, Sandiego, Ca., pp: 379-396.

Page, A.L., Miller, R.H. and Keeney, D.R. (1982). Methods of Soil Analysis. Part 2. Chemical and Microbiological Properties, $2^{\text {nd }}$ edition, Soil Sci. Soc. Amer. Inc. Madison, Wi. USA.

Parkinson, J. A. and Allen, S.E. (1975) A new oxidations procedure suitable for determination of nitrogen and mineral nutrients in biological materials, Commun, Soil. Sci.\& Plant Anal, 6: 1- 11.

Piper, C.S. (1950) Soil and Plant Analysis, Inter. Soc. Publ. Inc., New York, U.S.A.

Rama Rao, N. (1986) Potassium nutrition of pearl millet subjected to moisture stress., J. Potassium Res., 2: 1-12.

Reddya, A.R., Chaitanya, K.V. and Vivekanandanb, M. (2004) Drought induced responses of photosynthesis and antioxidant metabolism in higher plants, J. Plant Physiol., 161: 1189-1202.

Sarwar, N., Maqsood, M., Mubeen, K., Shehzad, M., Bhullar, M.S., Qamar, R. and Akbar, N. (2010) Effect of different levels of irrigation on yield and yield components of wheat cultivars, Pak. J. Agric. Sci., 47: 371-374.

SAS (2006) SAS Institute Inc., Cary Nc., USA (Soft Ware Statistical Program).
Schneider, A. D. and Howell, T. A. (1997) Methods, amounts and timing of sprinkler irrigation for winter wheat, Transaction of the ASAE., 40: 137-142.

Tiwari, H. S., Agarval, R.M. and Bhatt, R.K. (1998) Photosynthesis, stomatal resistance and related characters as influenced by potassium under normal water supply and water stress condition in rice (Oryza sativa L.), Indian $J$. Plant Physiol, 3: 314-316.

Umar, S. (2006) Alleviating adverse effects of water stress on yield of sorghum, mustard and groundnut by potassium application, Pakistan J. Bot., 38: 1373-1380.

Umar, S. and Moinuddin, M. (2002) Genotypic differences in yield and quality of groundnutas affected by potassium nutrition under erratic rainfall conditions, J. PlantNutr, 25: 1549-1562.

Zareian, A. H., Sharif, A. and Aidin, H. (2014) Yield, yield components and some physiological traits of three wheat (Triticum aestivum L.) cultivars under drought stress and potassium foliar application treatments, International Journal of Biosciences (IJB), 4 (5): 168-175.

Zhang, Y., Kendy, E., Qiang, Y., Changming, L., Yanjun, S. and Hongyong, S. (2004) Effect of soil water deficit on evapotranspiration, crop yield, and water use efficiency in the North China Plain, Agric. Water Manage, 64: 107-122.

Zwart, S. J. and Bastiaanssen, W. G. M. (2004) Review of measured crop water productivity values for irrigated wheat, rice, cotton and maize. Agric, Water Manage, 69: 115-133. 
تأثثر فترات الري وطرق إضافة البوتاسيوم على محصول القمح ومكوناته تحت نظام

حسين محمد علي راغب، وصالح محمود إسماعيل، وهالة حسانين جمعة، وأحمد محمد عبدالقوي

قسم الأراضي والمباه، كلية النراعة، جامعة أسيوط، جههورية مصر العربية

الدستخلص. أجريت تجارب حقلية لمدة موسمين متتاليين في محطة بحوث الأراضي والمياه التابعة

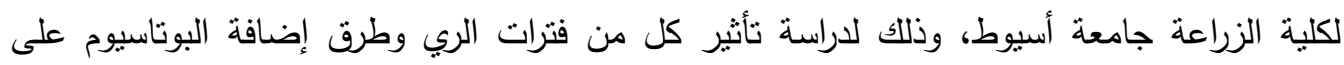

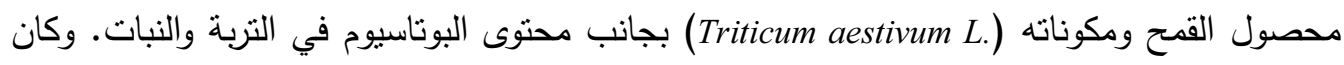
تصميم التجارب في نظام القطع المنثقة في أربعة مكررات حيث تضمنت القطع الرئيسة دراسة ثناث

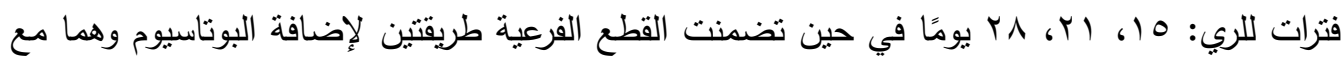

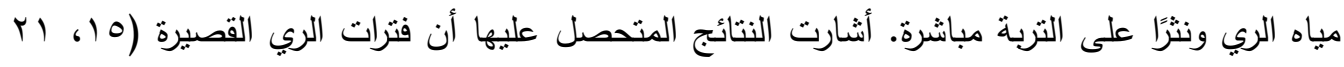

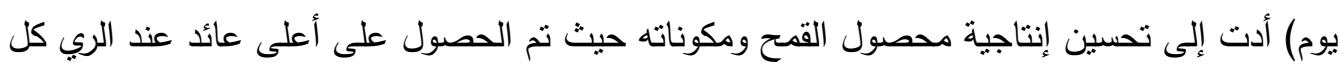

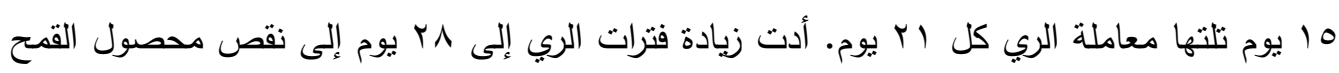

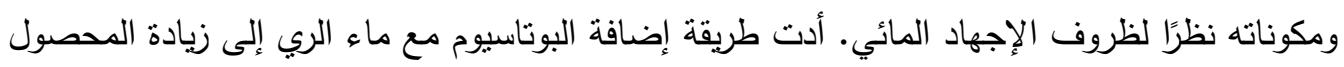

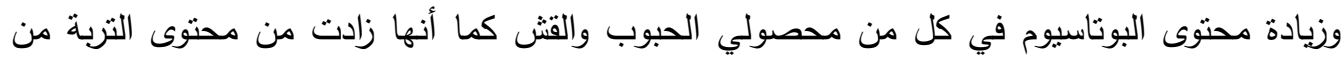
البوتاسيوم الدناح مقارنة مع طريقة إضافة البوتاسيوم نثرًا على التربة. الكلمات الدالة: الري بالتدفق، فترات الري، القمح، الأسمدة، البوتاسيوم، الري في خطوط. 